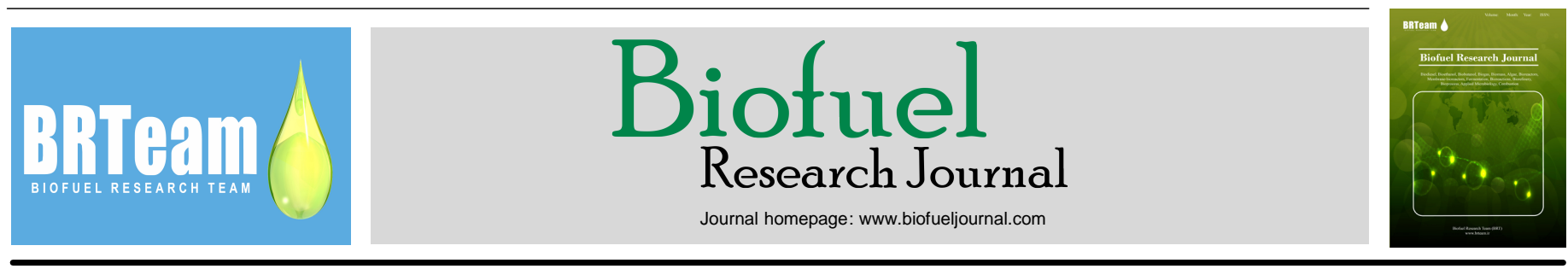

Review Paper

\title{
Methods for determination of biomethane potential of feedstocks: a review
}

\author{
Raphael Muzondiwa Jingura, Reckson Kamusoko*
}

Chinhoyi University of Technology, P. Bag 7724, Chinhoyi, Zimbabwe.

\section{HIGHLIGHTS}

$>$ The biomethane potential (BMP) provides baseline data for the performance of $\mathrm{AD}$.

$>$ Both experimental and theoretical methods to

determine BMP have been reviewed.

$>$ The BMP test is the most widely used method and

is credited for reliability and validity of its results.

\section{GRAPHICAL ABSTRACT}

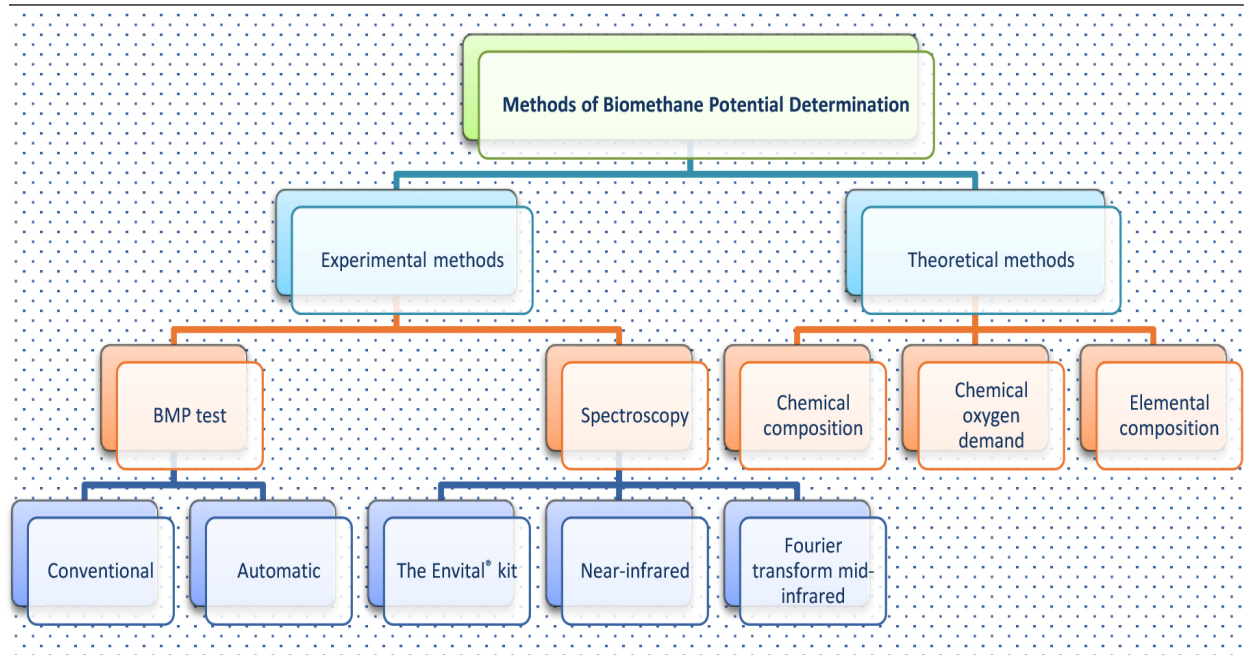

\begin{abstract}
Biogas is produced during anaerobic digestion $(\mathrm{AD})$ of biodegradable organic materials. AD is a series of biochemical reactions in which microorganisms degrade organic matter under anaerobic conditions. There are many biomass resources that can be degraded by $\mathrm{AD}$ to produce biogas. Biogas consists of methane, carbon dioxide, and trace amounts of other gases. The gamut of feedstocks used in AD includes animal manure, municipal solid waste, sewage sludge, and various crops. Several factors affect the potential of feedstocks for biomethane production. The factors include nutrient content, total and volatile solids (VS) content, chemical and biological oxygen demand, carbon/nitrogen ratio, and presence of inhibitory substances. The biochemical methane potential (BMP), often defined as the maximum volume of methane produced per $\mathrm{g}$ of VS substrate provides an indication of the biodegradability of a substrate and its potential to produce methane via AD. The BMP test is a method of establishing a baseline for performance of AD. BMP data are useful for designing AD parameters in order to optimise methane production. Several methods which include experimental and theoretical methods can be used to determine BMP. The objective of this paper is to review several methods with a special focus on their advantages and disadvantages. The review shows that experimental methods, mainly the BMP test are widely used. The BMP test is credited for its reliability and validity. There are variants of BMP assays as well. Theoretical models are alternative methods to estimate BMP. They are credited for being fast and easy to use. Spectroscopy has emerged as a new experimental tool to determine BMP. Each method has its own adva ntages and disadvantages with reference to efficacy, time, and ease of use. Choosing a method to use depends on various exigencies. More work needs to be continuously done in order to improve the various methods used to determine BMP.
\end{abstract}

(c) 2017BRTeam. All rights reserved.

* Corresponding author at: Tel.: +263 6727446

E-mail address: rkamsoko.kamusoko@gmail.com

Please cite this article as: Jingura R.M., Kamusoko R. Methods for determination of biomethane potential of feedstocks: a review. Biofuel Research Journal 14 (2017) 573-586. DOI: 10.18331/BRJ2017.4.2.3 


\section{Contents}

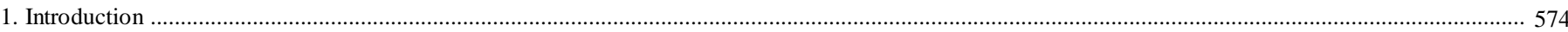

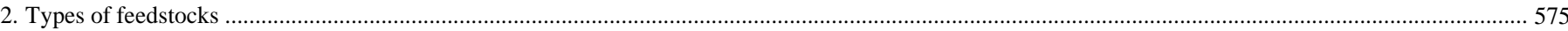

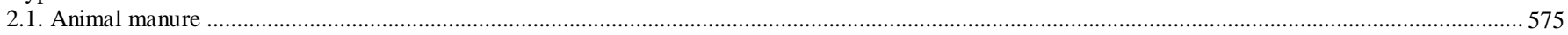

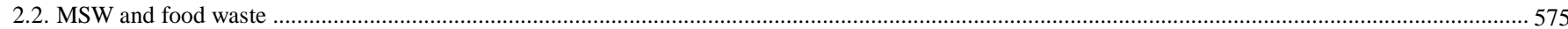

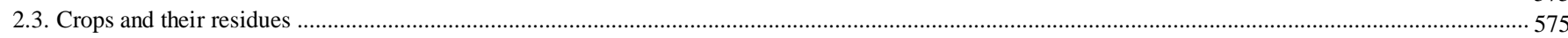

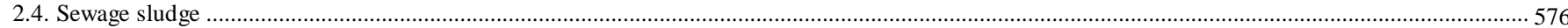

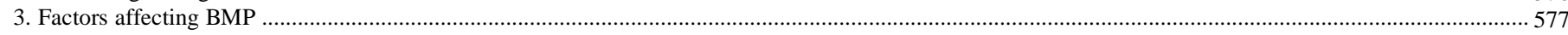

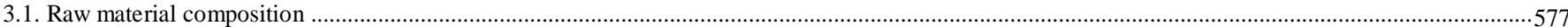

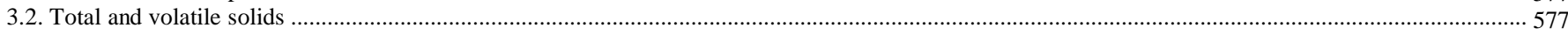

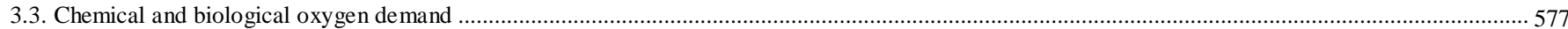

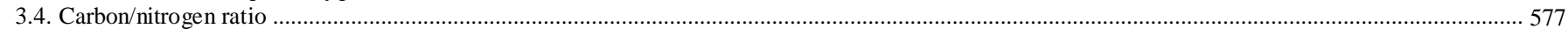

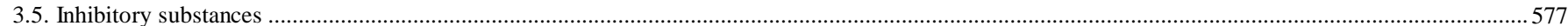

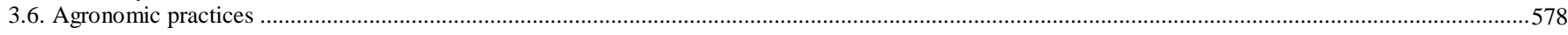

4. Methods for determining BMP …………

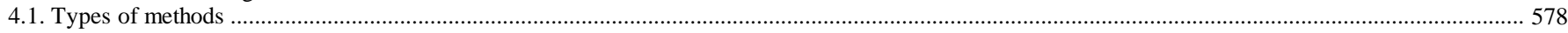

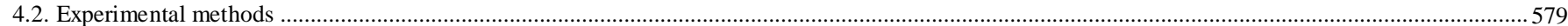

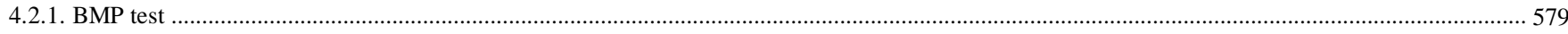

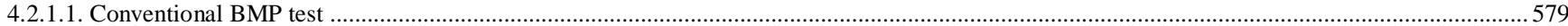

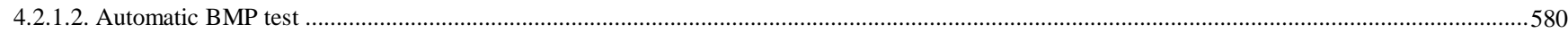

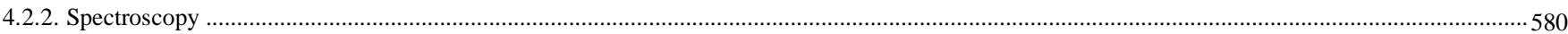

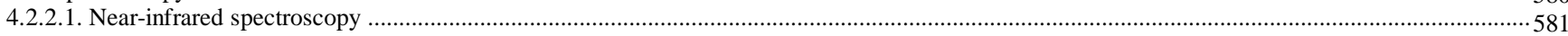

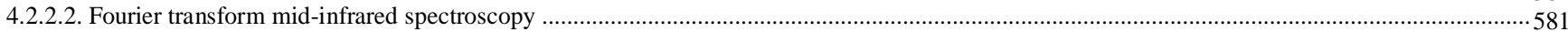

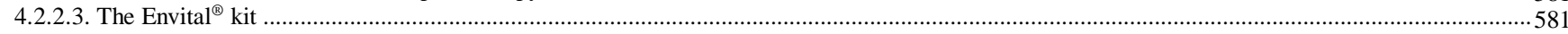

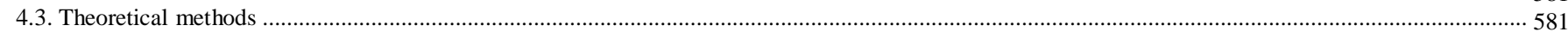

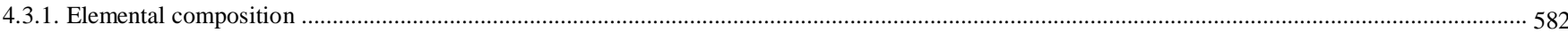

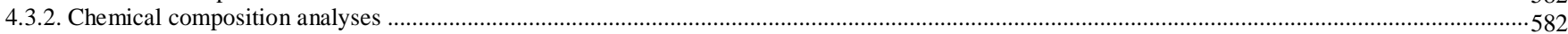

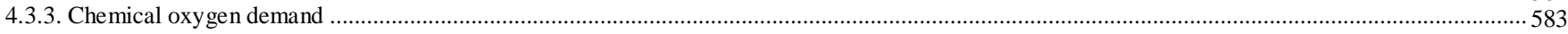

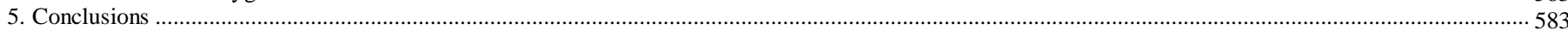

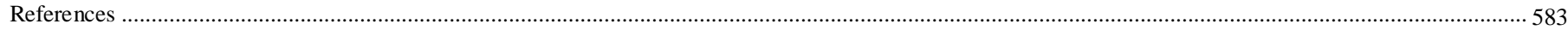

\begin{tabular}{|ll|}
\hline Abbreviations & \\
ABP & Anaerobic biogasification potential \\
AD & Anaerobic digestion \\
AMPTS & Automatic methane potential test system \\
BAM & Biogas activity monitoring \\
BMP & Biochemical methane potential \\
BOD & Biological (biochemical) oxygen demand \\
C/N & Carbon to nitrogen ratio \\
COD & Chemical oxygen demand \\
DM & Dry matter \\
eDOM & Enzymatically-digestible OM \\
FW & Food wastes \\
FTIR & Fourier transform mid-infrared spectroscopy \\
FTIR-PAS & FTIR-photoacoustic spectroscopy \\
GC & Gas chromatography \\
IR & Infrared \\
MIR & Mid-infrared \\
MSW & Municipal solid waste \\
NIR & Near-infrared spectroscopy \\
OFMSW & Organic fraction municipal solid waste \\
OM & Organic matter \\
SMA & Specific methanogenic activities \\
S/I & Substrate/inoculum \\
TOC & Total organic carbon \\
TS & Total solids \\
UV & Ultraviolet \\
VDI & Verein Deutscher Ingenieure \\
VIS & Visible \\
VFA & Volatile fatty acids \\
VS & Volatile solids \\
VSS & Volatile suspended solids \\
\hline
\end{tabular}

\section{Introduction}

Biogas is an energy carrier that contributes to the global energy mix. It is a combustible mixture of gases produced from degradable organic matter $(\mathrm{OM})$ by anaerobic digestion (AD). Biogas mainly consists of $60-70 \%$ methane $\left(\mathrm{CH}_{4}\right)$ and $30-40 \%$ carbon dioxide $\left(\mathrm{CO}_{2}\right)$. Other gases present include nitrogen
$\left(\mathrm{N}_{2}\right)$, hydrogen $\left(\mathrm{H}_{2}\right)$, hydrogen sulphide $\left(\mathrm{H}_{2} \mathrm{~S}\right)$ and ammonia $\left(\mathrm{NH}_{3}\right)$ (Kwietniewska and Tys, 2014). The gas also contains water vapour. Upgrading of biogas, i.e., purification and pressurizing, produces biomethane. Biomethane is an alternative fuel that can be a replacement for fossil fuels in both heat and power generation and is used as a vehicle fuel (Weiland, 2010). Auto manufacturers are already producing vehicles powered by biogas.

Environmental and socio-economic benefits for the society and the involved famers can be derived from the production of biogas. Biogas production improves local economic capabilities, safeguard jobs in rural communities, increases regional purchasing power, improves living standards and contributes to economic and social development (Al Seadi, 2008).

$\mathrm{AD}$ is a biochemical process whereby complex $\mathrm{OM}$ is degraded under anaerobic conditions by consortia of bacteria (Al Seadi, 2008). It is an ecofriendly process (Horváth et al., 2016) and one of the most efficient methods for conversion of biomass to $\mathrm{CH}_{4}$. $\mathrm{AD}$ is a complex microbial process occurring naturally in oxygen-free environments (Switzenbaum, 1995; Ward et al., 2008). It is a four-stage process comprising hydrolysis, acedogenesis, acetogenesis, and methanogenesis (Teghammar, 2013). The early stages require acidic operating conditions while $\mathrm{CH}_{4}$ is produced in later neutral conditions (Hobbs et al., 2007).

The degradation of OM takes place in individual steps carried out by different microorganisms, which place different requirements on the fermentation environment (Deublein and Steinhauser, 2008). Methanogenesis is the final stage. Methanogens use the products of acedogenesis and acetogenesis, such as $\mathrm{H}_{2}, \mathrm{CO}_{2}$, and acetate to produce biogas. This is either by breaking down the acids to $\mathrm{CH}_{4}$ and $\mathrm{CO}_{2}$, or by reducing $\mathrm{CO}_{2}$ with $\mathrm{H}_{2}$ (Monnet, 2003). In addition, $\mathrm{CO}$, formate, methanol, and methylamine can also be utilised to produce $\mathrm{CH}_{4}$ (Raju, 2012). Methanogenesis is a critical step in the entire AD process as it is the slowest biochemical reaction of the AD process (Al Seadi, 2008).

Based on the stages of operation, AD can be broadly classified into batch and continuous processes. The common difference between these two processes is that in the batch process, the steady state condition is never attained, while, in the continuous process, this is a pre-condition (Adhikari, 2006). Batch and continuous processes can either be single-stage or twostage systems. Single-stage systems are easy to design, construct, and 
operate and are generally less expensive. The initial hydrolysis and the acidproducing stage are separated from methanogenesis in two-stage systems allowing for higher loading rates. However, additional reactors and handling systems may be required in two-stage systems (California Integrated Waste Management Board; CIWMB, 2008). AD processes are carried out under laboratory conditions and scaled up to pilot-scale trials. The scalability and transferability of the biochemical methane potential (BMP) data generated in these trials will help take the results and apply them in larger-scale systems.

Many factors including feedstock characteristics, reactor design, and operational conditions may affect the performance of AD processes, either by process enhancement or inhibition (Babaee and Shayegan, 2011). Important feedstock parameters include volatile solids (VS) content, chemical oxygen demand (COD), biological (biochemical) oxygen demand (BOD), carbon to nitrogen ratio $(\mathrm{C} / \mathrm{N})$, and presence of inhibitory substances (Babaee and Shayegan, 2011; Kwietniewska and Tys, 2014).

All types of biomass can be used as feedstocks for biogas production as long as they contain carbohydrates, proteins, fats, cellulose, and hemicelluloses as the main components (Weiland, 2010). The gamut of biomass resources amenable to AD includes agricultural wastes, municipal solid waste (MSW), food waste, industrial waste and wastewater, and crops. Biomass resources differ significantly in parameters that influence biogas production. This affects their potential for biogas production by $\mathrm{AD}$. In order to optimise the $\mathrm{AD}$ process, it is important to know the potential production of biogas for a given feedstock (Schievano et al., 2009).

Anaerobic biogasification potential (ABP) and BMP are parameters used in evaluating biogas and methane potential of organic materials (Schievano et al., 2008). The BMP is often defined as the maximum volume of $\mathrm{CH}_{4}$ produced per $\mathrm{g}$ of VS substrate (Esposito et al., 2012). It provides an indication of the biodegradability of a substrate and its potential to produce $\mathrm{CH}_{4}$ via AD (Sell et al., 2010). Such information allows a direct assessment of biogas yields achieved by the AD process (Schievano et al., 2008). The BMP is also a good method for establishing baseline performance data of AD (Speece, 1996).

BMP assays have been widely used to determine the $\mathrm{CH}_{4}$ yield of organic substrates in AD (Gunaseelan, 2004). This premise is well established in the literature. In addition, BMP assays have been useful tools for determining the best substrates for co-digestion configurations (Nielfa et al., 2015). Over the years, a large number of papers dealing with anaerobic biodegradability tests for substrates of different origins have been published (Angelidaki, 2009). Typical papers have focused on either single specific methods or a narrow range of methods. This is less often with emphasis on comparative analysis. However, the importance of BMP in AD cannot be overemphasised. This paper provides a review of the disparate methods that have been used to determine BMP of various feedstocks. These include theoretical and experimental methods. A special focus is placed on their efficacy, advantages, and disadvantages.

\section{Types of Feedstocks}

It is important to start by providing a typology of the feedstocks that are used in $\mathrm{AD}$. Almost all types of biodegradable biomass can be used as feedstock for the AD process. Types of biomass resources used in $\mathrm{AD}$ include animal manure, MSW, sewage sludge, food waste, and crops. A brief description of the various feedstocks is provided in this section.

\subsection{Animal manure}

Animal manure is one of the common feedstocks for AD. Historically, animal manure has been the most common substrate for biogas production in $\mathrm{AD}$ process. There are significant populations of livestock in many countries. Livestock produce large amounts of manure which are suitable substrates for AD. Manure is a mixture of faeces and urine, and its chemical composition varies markedly depending on the chemical characteristics of the feed consumed by the animal. Animal manure comprises huge amounts of lignocelluloses, polysaccharides, proteins, and other biomaterials (United States Department of Energy; USDE, 2003). The compositions of these parameters in manure produced by different animals are presented in Table 1 .

\subsection{MSW and food waste}

The food industry and municipal authorities produce various types of organic wastes. These include food wastes (FW) and MSW. The wastes consist of several different fractions of organic and inorganic nature. MSW is traditionally sorted into six categories, which are: food residue, wood waste, paper, textiles, plastics, and rubber as shown in Table 2 (Zhou et al., 2014).

Separation of MSW into the putrescible organic fraction has been known to provide a good quality feedstock for AD (International Energy Agency; IEA, 2013). This fraction of MSW is called the organic fraction municipal solid waste (OFMSW). The OFMSW is characterised by high moisture and high biodegradability due to a large content of food waste, kitchen waste, and leftovers from residences, restaurants, cafeterias, factory lunch-rooms, and markets (Zhang et al., 2007; Lebersorger and Schneider, 2011).

The most predominant fraction of the OFMSW is FW (Browne and Murphy, 2013; De Clercq et al., 2016). FW consists of kitchen waste and food processing waste (Ye et al., 2015). Its composition is heterogeneous and varies from place to place. The chemical composition of FW is presented in Table 2. FW composition is also determined by whether the waste has been segregated on the basis of source or is from a co-mingled source, separated at materials recovery facility (Allen et al., 2013). FW is easily biodegradable and has high methane potential yield (Strong et al., 2016).

\subsection{Crops and their residues}

A number of crops demonstrate good biogas production potential. Different cereal crops and perennial grasses have potential as energy crops. Many forage crops produce large amounts of easily degradable biomass which is necessary for high biogas yield (Braun et al., 2009). The most important parameter for choosing energy crops is their net energy yield per

Table 1.

Comparison of protein, fibre, and lignocellulose compositions of cattle, poultry, and swine manures (\% dry matter)*.

\begin{tabular}{|c|c|c|c|c|c|c|c|c|c|c|}
\hline \multirow{2}{*}{ Parameter } & \multicolumn{3}{|c|}{ Cattle manures } & \multicolumn{3}{|c|}{ Swine manures } & \multicolumn{4}{|c|}{ Poultry manures } \\
\hline & Dairy & Beef & Feedlot & Nursery & Grower & Finisher & Chick starter & Pullet grower & $17-40$ weeks & Post-molt diet \\
\hline Crude protein & 18.1 & 12.1 & 17.0 & 25.1 & 22.7 & 22.0 & 39.8 & 48.4 & 31.6 & 28.0 \\
\hline Total fibre & 52.6 & 51.5 & 41.7 & 39.2 & 40.8 & 39.1 & 31.7 & 36.4 & 34.5 & 31.2 \\
\hline Hemicellulose & 12.2 & 17.4 & 21.4 & 21.9 & 20.5 & 20.4 & 18.3 & 21.5 & 20.2 & 16.4 \\
\hline Cellulose & 27.4 & 21.9 & 14.2 & 13.2 & 13.9 & 13.3 & 8.5 & 7.7 & 12.0 & 10.7 \\
\hline Lignin & 13.0 & 12.2 & 6.1 & 4.1 & 6.4 & 5.4 & 4.9 & 7.2 & 2.3 & 4.1 \\
\hline
\end{tabular}

* Source: USDE (2003) 
Table 2.

Chemical composition of MSW.

\begin{tabular}{|c|c|c|c|c|c|c|c|c|}
\hline \multirow{2}{*}{ Type of waste } & \multicolumn{3}{|c|}{ Proximate (wt.\% on dry weight basis) } & \multicolumn{5}{|c|}{ Ultimate (wt.\% on dry weight ash-free basis) } \\
\hline & Ash & Volatiles & Fixed carbon & Carbon & Hydrogen & Oxygen & Nitrogen & Sulphur \\
\hline \multicolumn{9}{|l|}{ Food residue } \\
\hline Vegetable & 19.0 & 70.7 & 10.3 & 45.0 & 5.5 & 45.4 & 3.4 & 0.6 \\
\hline Fruit peel & 3.9 & 77.7 & 18.4 & 48.7 & 6.2 & 43.1 & 1.2 & 0.2 \\
\hline Bone & 36.3 & 59.2 & 4.5 & 58.0 & 7.2 & 25.4 & 8.7 & 0.7 \\
\hline Starch food & 0.6 & 87.3 & 12.1 & 43.4 & 6.3 & 48.2 & 2.0 & 0.1 \\
\hline Nutshell & 2.0 & 74.2 & 23.7 & 52.7 & 6.7 & 39.3 & 1.2 & 0.2 \\
\hline \multicolumn{9}{|l|}{ Wood waste } \\
\hline Wood & 1.6 & 83.1 & 15.3 & 50.3 & 6.1 & 43.0 & 0.4 & 0.1 \\
\hline Bamboo & 1.5 & 81.0 & 17.5 & 49.4 & 6.0 & 44.2 & 0.4 & 0.2 \\
\hline Leaves & 7.9 & 75.0 & 17.2 & 50.0 & 5.5 & 43.5 & 0.7 & 0.4 \\
\hline Weeds & 6.0 & 77.0 & 17.0 & 50.4 & 6.6 & 42.2 & 0.7 & 0.2 \\
\hline \multicolumn{9}{|l|}{ Paper } \\
\hline Printing paper & 11.4 & 78.9 & 9.7 & 45.5 & 6.3 & 47.7 & 0.2 & 0.2 \\
\hline Cardboard & 8.3 & 79.9 & 11.9 & 47.9 & 6.2 & 45.4 & 0.3 & 0.2 \\
\hline Toilet paper & 0.3 & 92.9 & 6.8 & 43.7 & 6.0 & 50.0 & 0.1 & 0.2 \\
\hline \multicolumn{9}{|l|}{ Textiles } \\
\hline Cotton & 1.1 & 87.9 & 11.0 & 47.6 & 6.3 & 45.1 & 0.8 & 0.1 \\
\hline Wool & 1.2 & 84.8 & 14.0 & 59.3 & 5.4 & 24.9 & 8.9 & 1.6 \\
\hline Chemical fibres & 2.2 & 87.1 & 10.8 & 59.3 & 5.3 & 27.4 & 7.6 & 0.5 \\
\hline \multicolumn{9}{|l|}{ Plastics } \\
\hline Polyethylene & 0.3 & 99.6 & 0.1 & 85.6 & 14.2 & 0.1 & 0.1 & 0.1 \\
\hline Polypropylene & 0.4 & 99.5 & 0.03 & 85.0 & 13.9 & 1.0 & 0.1 & 0.01 \\
\hline Polystyrene & 0.2 & 99.5 & 0.3 & 90.4 & 8.6 & 0.9 & 0.00 & 0.1 \\
\hline Polyvinyl chloride & 5.9 & 83.5 & 10.7 & 39.6 & 4.9 & 0.02 & 0.1 & 0.3 \\
\hline Polyethylene terephthalate & 0.2 & 92.3 & 7.5 & 62.3 & 4.4 & 33.1 & 0.1 & 0.0 \\
\hline Rubber & 10.2 & 67.4 & 22.4 & 85.0 & 8.3 & 4.1 & 0.9 & 1.6 \\
\hline
\end{tabular}

Source: Zhou et al. (2014)

hectare (Weiland, 2010). Other factors considered include optimum time of harvesting and methane yield per hectare (Amon et al., 2007).

Non-food crops can also be used for biogas production. Examples are Jatropha curcas L. press-cake (Jingura et al., 2010; Navarro-Pineda et al., 2016) and Arundo donax L. (Corno et al., 2014). A. donax has been used in codigestion with animal slurries and/or other biomasses (Corno et al., 2014). Production of biogas by AD of $J$. curcas press-cake has been demonstrated. The observed biogas production from J. curcas press-cake was about $60 \%$ higher than cattle dung and the gas contained 66\% methane (Singh et al., 2008).

Several crop residues including cotton, maize, and rice residues have shown high potential for AD (Isci and Demir, 2007). However, high lignin content of some straws and other residues can lead to poor biodegradability and low biogas production. Table 3 shows the dry matter and lignocellulose contents of selected crops and crop residues. Pre-treatment of lignocellulosic materials improves biodegradability and the biogas production, and decreases the hydraulic retention time (Ertem, 2011; Chandra et al., 2012). In an investigation, Chandra et al. (2012) provided a good review of biomethane production from lignocellulosic agricultural wastes. They obtained $87.5 \%$ higher biogas yield and $111.6 \%$ higher $\mathrm{CH}_{4}$ yield from $\mathrm{NaOH}$ pre-treated wheat straw compared with non-treated wheat straw substrate. A similar study by Nges (2012) produced viable methane yield through pre-treatment, nutrient addition, and co-digestion of crop and waste biomass.

\subsection{Sewage sludge}

Worldwide the anaerobic stabilization of sewage sludge is probably the most prevalent AD activity. Sewage sludge is produced in large quantities in urban areas all over the world. It is a vast resource that has high 
Table 3.

Dry matter and lignocellulose composition of selected crop and crop residues*.

\begin{tabular}{lllll}
\hline Feedstock & $\begin{array}{l}\text { Dry matter } \\
(\mathbf{D M}) \\
\left(\mathbf{g ~ k g}^{-1} \mathbf{w} / \mathbf{w}\right)\end{array}$ & $\begin{array}{l}\text { Cellulose } \\
(\% \text { of } \mathbf{D M})\end{array}$ & $\begin{array}{l}\text { Hemicellulose } \\
(\% \text { of DM })\end{array}$ & $\begin{array}{l}\text { Lignin } \\
(\% \text { of DM })\end{array}$ \\
\hline Forestry residues & & & & \\
Black locust & - & 42 & 18 & 27 \\
Hybrid poplar & - & 45 & 19 & 26 \\
Eucalyptus & - & 50 & 13 & 28 \\
Spruce & - & 43 & 26 & 29 \\
Pine & - & 45 & 20 & 29
\end{tabular}

\section{Crop residues}

$\begin{array}{lllll}\text { Barley straw } & 88.7 & 43 & 30 & 7 \\ \text { Corn stover } & 86.2 & 46 & 35 & 19 \\ \text { Rice straw } & 88.6 & 40 & 18 & 7 \\ \text { Sorghum straw } & 89.0 & 44 & 35 & 15 \\ \text { Wheat straw } & 89.1 & 40 & 28 & 16 \\ \text { Baggase } & 26.0 & 33 & 30 & 29\end{array}$

Grasses

\begin{tabular}{lllll} 
Perennial grass & 28.8 & 29 & 26 & 6 \\
Perennial grass & 235.0 & 27 & 28 & 3 \\
Dried wild grass & 93.4 & 36 & 23 & 6 \\
Grass & 187.4 & 30 & 27 & 2 \\
Grass & 180.2 & 26 & 21 & 1 \\
\hline
\end{tabular}

* Sources: Triolo et al. (2011) and Ho et al. (2014)

biodegradability. Wastewater treatment facilities use anaerobic digesters to break down sewage sludge and eliminate pathogens in wastewater (Scaglia et al., 2014).

The AD of sewage sludge provides significant benefits as it leads to the production of energy in the form of biogas and help waste management. In the Europe, typically between $30 \%$ and $70 \%$ of sewage sludge is treated by AD (IEA, 2009). Most developing countries lack sanitation facilities, therefore, AD is in most cases the only treatment of wastewater (Noyola et al., 2006).

\section{Factors affecting BMP}

The biogas yield of the individual substrates varies considerably depending on their origin, content of organic substance, and substrate composition (Weiland, 2010). Chemical constituents of biomass resources include carbohydrates, proteins, fats, cellulose, and hemicelluloses as main components. Feedstocks differ markedly in their chemical composition. As such, the amount and the composition of biogas vary from one substrate to another (Mayer et al., 2014).

\subsection{Raw material composition}

Methane yield vary for different chemical constituents of the same feedstock. Basegra (1998) cited by Weiland (2010), provided maximal gas yield and theoretical methane contents for carbohydrates, fats, proteins, and lignin that are shown in Table 4. Fats and proteins produce more methane than carbohydrates and lignin is not biodegradable under AD.

\subsection{Total and volatile solids}

Total solids (TS) indicate organic and inorganic portion of matter. OM is measured by the amount of carbon in a feedstock (Hamilton, 2012). TOC is the total organic carbon in feedstocks. VS are the OM component of TS. Methane production is directly related to VS degradation (Moody et al., 2009).

The TS content of feedstock influences AD performance, especially biogas production efficiency (Pavan et al., 2000). Systems used in AD are classified according to the percentage of TS in the feedstock (Yi et al., 2014). There are
Table 4.

Maximal gas yields and theoretical methane contents*.

\begin{tabular}{lccc}
\hline Substrate & Biogas $\left(\mathbf{N m}^{3} \mathbf{t}^{-1} \mathbf{T S}\right)$ & $\mathbf{C H}_{\mathbf{4}}(\mathbf{\%})$ & $\mathbf{C O}_{\mathbf{2}}(\mathbf{\%})$ \\
\hline Raw fat & $1200-1250$ & $67-68$ & $32-33$ \\
Carbohydrates $^{\mathrm{a}}$ & $790-800$ & 50 & 50 \\
Raw protein & 700 & $70-71$ & $29-30$ \\
Lignin & 0 & 0 & 0 \\
\hline $\begin{array}{l}\text { a Only polymers from hexoses, not inulins and single hexoses. } \\
\text { * Source: Weiland (2010) }\end{array}$
\end{tabular}

three main types of AD technologies that work according to the TS content of feedstocks (Yi et al., 2014). These are: conventional wet ( $\leq 10 \%$ TS), semi-dry (10-20\% TS) and modern dry ( $\geq 20 \%$ TS) processes (Yi et al., 2014). Abbassi-Guendouz et al. (2012) showed that total methane yield decreased with TS contents increasing from $10 \%$ to $25 \%$ in batch AD of cardboard under mesophilic conditions. Similarly, Forster-Carneiro et al. (2008) showed that biogas and methane production decreased when the TS contents increased from $20 \%$ to $30 \%$ in dry batch $\mathrm{AD}$ of food waste.

There is evidence that methane yield increases with increasing content of volatile products and less hemicelluloses (Gao et al., 2012). Biomethane yield is affected by VS content (Mayer et al., 2014). In fact, there is a high correlation between VS and both ABP and BMP (Mayer et al., 2014).

\subsection{Chemical and biological oxygen demand}

COD is used to quantify the amount of OM in feedstocks and predicts the potential for biogas production (des Mes et al., 2003). Theoretical methane yield can be calculated from the COD of a substrate (Kwietniewska and Tys, 2014). Biogas production in relation to COD is about $0.5 \mathrm{~L} \mathrm{~g}^{-1} \mathrm{COD}$ removed, corresponding to a methane production of approximately $0.35 \mathrm{~L} \mathrm{~g}^{-1}$ of COD removed (Angelidaki and Sanders, 2004).

Another widely used parameter is the BOD which is a measure of the oxygen used by microorganisms to decompose OM. BOD is similar to COD in that both measure the amount of OM. Examples of typical BOD values are: pig slurry $20,000-30,000$, cattle slurry $10,000-20,000$ and wastewater $1000-5000 \mathrm{mg} \mathrm{L}^{-1}$ (Korres et al., 2013).

\subsection{Carbon/nitrogen ratio}

The $\mathrm{C} / \mathrm{N}$ ratio represents the relationship between the amount of nitrogen and carbon in a feedstock. A feedstock $\mathrm{C} / \mathrm{N}$ ratio of $25: 1$ produces optimal gas production (Gerardi, 2003). The optimum range of $\mathrm{C} / \mathrm{N}$ ratio for $\mathrm{AD}$ is 20-35:1 (Kwietniewska and Tys, 2014). A low ratio means that the material is protein rich. $\mathrm{AD}$ of such material results in increased content of free ammonia that causes high $\mathrm{pH}$ leading to methanogenic inhibition (Khalid et al., 2011). A high ratio causes rapid depletion of nitrogen causing lower gas production.

Wang et al. (2014) reported an interactive effect between temperature and $\mathrm{C} / \mathrm{N}$ on $\mathrm{AD}$ performance. They rereported that when temperature was increased, a higher $\mathrm{C} / \mathrm{N}$ ratio would be required in order to reduce the risk of ammonia inhibition. Typical $\mathrm{C} / \mathrm{N}$ ratios for some feedstocks are: cattle manure $13: 1$, chicken manure $15: 1$, grass silage $25: 1$ and rice husks $47: 1$ (Dioha et al., 2013).

\subsection{Inhibitory substances}

Feedstocks may contain substances that can inhibit AD. The levels of inhibitory substances in feedstocks need to be managed and guidelines are available. A material may be judged inhibitory when it causes an adverse shift in the microbial population or inhibition of bacterial growth (Chen et al., 2008).

The inhibitors are commonly $\mathrm{NH}_{3}, \mathrm{H}_{2} \mathrm{~S}$, and heavy metals (Gerardi, 2003). Free $\mathrm{NH}_{3}$ is the main cause of inhibition since it is freely membranepermeable (de Baere et al., 1984). Methanogens have the least tolerance to 
$\mathrm{NH}_{3}$ inhibition amongst all the microbes in anaerobic digesters (Chen et al., 2008).

\subsection{A gronomic practices}

Nowadays there are efforts to improve the biomethane yield from cropbased feedstocks. In order to optimise biomethane yield from crops, factors that influence BMP and biomass yield should be identified and managed (Mayer et al., 2014). Factors such as agro-climatic conditions, soil characteristics, plant varieties, and agronomic practices influence both the composition and yield of crops. The biomass composition then influences the ABP and the methane content in the biogas leading to various BMP values (Schittenhelm, 2008; Oslaj et al., 2010; Gao et al., 2012). Mahmood et al. (2013) showed significant variations across plant variety on specific methane yield and maize cv. Agrogas reportedly had the highest methane yield of $367 \mathrm{NL} \mathrm{kg} \mathrm{VS}^{-1}$. This was attributed to high starch and low lignin content of maize cv. Agrogas. In a study by Sepalla (2013) to evaluate the methane production potential of traditional and novel energy crops in boreal conditions, maize attained the greatest methane potential ranging from 4,000 to $9,200 \mathrm{~m}^{3} \mathrm{CH}_{4} \mathrm{ha}^{-1} \mathrm{a}^{-1}$.

Several crops, as highlighted earlier, are good feedstocks for AD. Biomethane yield per unit of cropped area can be improved (Mayer et al., 2014). Mayer et al. (2014) provided Equation 1 for calculating the biomethane yield from crop production systems as:
Biomethane yield $\left(\mathrm{m}^{3} \mathrm{CH}_{4} h a^{-1}\right)=\mathrm{BMP}\left(\mathrm{m}^{3} \mathrm{CH}_{4} t^{-1}\right) \times$ biomass yield $\left(t h a^{-1}\right)$

(Eq. 1)

The utility of Equation 1 will be shown later with regard to use of ABP values to calculate BMP values as presented by Mayer et al. (2014).

In their study with maize, Mayer et al. (2014) achieved an average biomethane yield per hectare of $7,266 \mathrm{~m}^{3} \mathrm{ha}^{-1}$. It was concluded that the cropping environment was responsible for most of the variation of the biomethane yield per hectare. They also reported a decrease in biomethane yield with stage of maturity of the maize crop. This can be ascribed to increased content of structural carbohydrates and lignin in the plants.

Stage of maturity of a crop affects its chemical composition, which in turn affects BMP. However, Schittenhelm (2008) reported that despite substantially different nutrient concentration among some maize hybrids used in a trial, no clear-cut association existed between chemical composition and specific methane yield. This variation could be due to variation in chemical content within critical limits to affect BMP.

\section{Methods for determining BMP}

\subsection{Types of methods}

Numerous alternative options have been proposed to estimate the BMP of organic substrates (Hansen et al., 2004). Basically, the methods use the

Table 5.

Selected BMP values of various materials measured by different methods.

\begin{tabular}{|c|c|c|c|}
\hline Method & Substrate & BMP value & Reference \\
\hline \multicolumn{4}{|l|}{ BMP test } \\
\hline \multirow[t]{6}{*}{ Conventional } & Floatable oil skimmed from food waste & $608-847 \mathrm{~mL} \mathrm{~g}^{-1}$ & Meng et al. (2015) \\
\hline & Grass silage from ryegrass (Loliumperenne) & $400 \mathrm{~L} \mathrm{CH}_{4} \mathrm{~kg} \mathrm{VS}^{-1}$ & Wall et al. (2013) \\
\hline & Fresh dairy slurry & $239 \mathrm{~L} \mathrm{CH}_{4} \mathrm{~kg} \mathrm{VS}^{-1}$ & \\
\hline & Piglet manure & $417 \mathrm{NL} \mathrm{CH}_{4} \mathrm{~kg} \mathrm{VS}^{-1}$ & Triolo et al. (2011) \\
\hline & Maize & $399 \mathrm{NL} \mathrm{CH}_{4} \mathrm{~kg} \mathrm{VS}^{-1}$ & \\
\hline & Straw & $290 \mathrm{NL} \mathrm{CH}_{4} \mathrm{~kg} \mathrm{VS}^{-1}$ & \\
\hline \multirow[t]{5}{*}{ Automatic } & Pre-treated sugarcane bagasse & $200 \mathrm{NL} \mathrm{CH}_{4} \mathrm{~kg} \mathrm{VS}^{-1}$ & Badshah et al. (2012) \\
\hline & Cellulose & $366 \mathrm{~mL} \mathrm{CH}_{4} \mathrm{~g} \mathrm{VS}^{-1}$ & Wang et al. (2014) \\
\hline & Glycerol & $300-310 \mathrm{~m}^{3} \mathrm{Mg}^{1}$ & Kuusiki et al. (2013) \\
\hline & Raw sludge & $140-230 \mathrm{~m}^{3} \mathrm{Mg}^{-1}$ & \\
\hline & Fish farming residues & $260 \mathrm{~m}^{3} \mathrm{Mg}^{-1}$ & \\
\hline \multicolumn{4}{|l|}{ Spectroscopy } \\
\hline \multirow{2}{*}{ Near-infrared spectroscopy } & Municipal solid waste & $61 \mathrm{~mL} \mathrm{CH}_{4} \mathrm{~g}^{-1} \mathrm{VS}$ & Lesteur et al. (2011) \\
\hline & Plant biomass & $136-478 \mathrm{NL} \mathrm{CH}_{4} \mathrm{~kg} \mathrm{VS}^{-1}$ & Triolo et al. (2014) \\
\hline Fourier transform mid-infrared & Grasses: class I & $227 \mathrm{NL} \mathrm{CH}_{4} \mathrm{~kg} \mathrm{VS}^{-1}$ & Bekiaris et al. (2015) \\
\hline spectroscopy & class II & $327 \mathrm{NL} \mathrm{CH}_{4} \mathrm{~kg} \mathrm{VS}^{-1}$ & \\
\hline \multirow[t]{2}{*}{ The Envital ${ }^{\circledast}$ kit } & Primary sludge & $720 \mathrm{NmL} \mathrm{CH}_{4} \mathrm{~g}^{-1} \mathrm{VS}$ & Bellaton et al. (2016) \\
\hline & Tertiary sludge & $640 \mathrm{NmL} \mathrm{CH}_{4} \mathrm{~g}^{-1} \mathrm{VS}$ & \\
\hline \multicolumn{4}{|l|}{ Theoretical methods } \\
\hline & Grass silage from ryegrass & $443 \mathrm{~L} \mathrm{CH}_{4} \mathrm{~kg} \mathrm{VS}^{-1}$ & Wall et al. (2013) \\
\hline & Fresh dairy slurry & $389 \mathrm{~L} \mathrm{CH}_{4} \mathrm{~kg} \mathrm{VS}^{-1}$ & \\
\hline & Piglet manure & $450 \mathrm{NL} \mathrm{CH}_{4} \mathrm{~kg} \mathrm{VS}^{-1}$ & Triolo et al. (2011) \\
\hline & Maize & $452 \mathrm{NL} \mathrm{CH}_{4} \mathrm{~kg} \mathrm{VS}^{-1}$ & \\
\hline & Straw & $448 \mathrm{NL} \mathrm{CH}_{4} \mathrm{~kg} \mathrm{VS}^{-1}$ & \\
\hline
\end{tabular}


same principle, but the technical approaches and experimental setups may be different (Rodriguez, 2011). Most studies have attempted to assess biodegradability of OM or BMP by estimating the content of organic constituents while a few have focused on lignin (Triolo et al., 2011).

The available methods are either experimental or theoretical. These methods will be discussed in this section. Within each category there are variants. Table 5 presents the differences among BMP methods in terms of measured BMP values. Most experimental techniques are batch methods. However, novel approaches to determine BMP are required since the current protocols are expensive and time-wasting (Triolo et al., 2011). As such, cost and time are critical parameters in choice of method.

\subsection{Experimental methods}

\subsubsection{BMP test}

The BMP test is the most widely used technique to determine BMP and ascertains the effectiveness of $\mathrm{AD}$ process and the biodegradability of substrate (Esposito et al., 2012). It is a laboratory-scale batch assay of 30-100 d of sample's AD (Godin et al., 2015). BMP test provides important information that can be used to develop mathematical models for prediction of BMP of feedstocks (Angelidaki et al., 2009; Esposito et al., 2012).

The BMP test has several variants. There have been several trials to define a standard protocol for ultimate BMP test in order to achieve comparable results. As of the year 2012, standardisation was not met (Esposito et al., 2012). More recently, Koch et al. (2015) reported that despite the wide use of BMP test, no commonly accepted experimental procedure yet exists that is based on a standardised protocol for the execution of the test. This can be attributed to the fact that $\mathrm{AD}$ is a very complex and dynamic system in which microbiological, biochemical, and physio-chemical characteristics are closely related (Angelidaki et al., 2009).

It is worth noting that despite lack of agreement on standard protocols, some BMP procedures exist that are used by various researchers. The three commonly used methods include the German standard procedure, Verein Deutscher Ingenieure (VDI) 4630 (VDI method), the Møller method and the Hansen method (Pham et al., 2013). These methods vary in their operational conditions as shown in Table 6. The VDI method provides information regarding the methodology for performing fermentation tests in batch and continuous mode (VDI 4630, 2006).

Table 6.

Comparison of the most widely used methods for the determination of BMP*

\begin{tabular}{llll}
\hline Operational conditions & VDI method & Møller method & Hansen method \\
\hline AD conditions & $\begin{array}{l}\text { Thermophilic or } \\
\text { mesophilic }\end{array}$ & Mesophilic & Thermophilic \\
Temperature $\left({ }^{\circ} \mathrm{C}\right)$ & 37 or 55 & 37 & 55 \\
Inoculum & $\begin{array}{l}\text { Thermophilic or } \\
\text { mesophilic }\end{array}$ & Mesophilic & Thermophilic \\
\hline
\end{tabular}

* Source: Pham et al. (2013)

Angelidaki et al. (2009) cited the protocol published by the Task Group for the Anaerobic Biodegradation, Activity and Inhibition of the Anaerobic Digestion Specialist Group of the International Water Association in 2009 as one of the most applied standard protocols. The ISO 11734 (ISO 11734, 1995) is another protocol that is occasionally used.

Several techniques including manometric, volumetric, and gas chromatography methods can be used to measure gas production (European Communities; EC, 2002). Volumetric methods measure the amount of biogas or only the volume of methane generated during $\mathrm{AD}$ of compound. The volume is either measured by displacement of a piston of syringe or as part of the reactor or by water displacement technique (EC, 2002). The manometric techniques derived from Warburg's respirometer measure the gas produced in constant volume by pressure increase by a differential manometer (EC, 2002).
The amount of $\mathrm{CH}_{4}$ and $\mathrm{CO}_{2}$ of the biogas that ends up in the headspace of closed vials is measured by means of gas chromatography (GC) (EC, 2002).

Standard protocols provide information that clearly demonstrate the setting of parameters that considerably influence the test results. These parameters include temperature, $\mathrm{pH}$, stirring intensity, physico-chemical characteristics of substrates, and substrate/inoculum (S/I) ratio (Esposito et al., 2012). Effects of these parameters on the efficacy of the BMP test are summarised in Table 7.

Most of the BMP tests described in the literature are conventional tests. Nowadays, automatic BMP tests with greater precision, and minimum time and labor requirements have been developed (Shi, 2012).

\subsubsection{Conventional BMP test}

The general principle of the conventional BMP test is to mix an organic feedstock with an inoculum in distinct operational conditions, and physically quantify the gas produced by manometric or volumetric method. The biogas composition is determined by GC (Esposito et al., 2012). BMP values are given as either the sample volume $\left(\mathrm{m}^{3} \mathrm{CH}_{4} \mathrm{~m}^{-3}\right.$ sample), sample mass $\left(\mathrm{m}^{3} \mathrm{CH}_{4} \mathrm{~kg}^{-1}\right.$ sample) or sample organic content $\left(\mathrm{m}^{3} \mathrm{CH}_{4} \mathrm{~kg}^{-1} \mathrm{COD}\right)$ (Zaman, 2010).

The conventional BMP test is generally criticised to be time wasting and resource consuming, although it is simple, repeatable and relatively cheap (Rodriguez, 2011; Esposito et al., 2012).

The technical approaches and experimental set up of BMP test vary significantly (Rodriguez, 2011). For example, a BMP test described by Zaman (2010) consisted of $250 \mathrm{~mL}$ reagent bottles, and rubber serum caps, gassed with a mixture of $30 \% \mathrm{CO}_{2}$ and $70 \% \mathrm{~N}_{2}$ for $15 \mathrm{~min}$, then plugged and equilibrated at incubation temperature. The gas evolved was measured volumetrically by a syringe, and the $\mathrm{CH}_{4}$ content was calculated as the difference between background values obtained from seed blanks and from the sample totals (Zaman, 2010).

The specific methanogenic activities (SMA) test on anaerobic biomass is also an important assay to traditionally evaluate the biochemical activities of organisms present in the biomass (Jijai et al., 2014), and the $\mathrm{CH}_{4}$ producing potential for a particular substrate at the concentration level where the presence of substrate is not a limiting factor (Hussain and Dubey, 2017).

The SMA is determined by mixing known quantities of biomass and supplementary substrate in a serum bottle in concentrations enough to allow maximum biogas activity (Jijai et al., 2014). The whole test is carried out in a controlled cabin at $35^{\circ} \mathrm{C}$. The resultant $\mathrm{CH}_{4}$ gas production is estimated by liquid displacement technique (Hussain and Dubey, 2017). The amount of COD and volatile suspended solids (VSS) are also determined using the standard methods. Plotting the $\mathrm{CH}_{4}$ production (g COD) against time (d) and divided by g VSS added is used to estimate the SMA. The SMA is given as methane produced $\left(\mathrm{g} \mathrm{CH}_{4}-\mathrm{COD}\right) \mathrm{g}^{-1}$ VSS (added) (Hussain and Dubey, 2017).

The ABP is yet another potential conventional assay that can directly determine the biogas output in $\mathrm{AD}$ processes. The assay is regarded as the same as the BMP test (Schievano et al., 2008). It is also criticised for being time-consuming as it requires up to $60 \mathrm{~d}$ (Schievano et al., 2009). In the case of ABP assay, the batch tests are conducted in sealed serum bottles containing an inoculum, sample, and de-ionised water. The bottles are flushed with nitrogen atmosphere followed by incubation for approximately $60 \mathrm{~d}$ at $37^{\circ} \mathrm{C}$, until no more biogas is produced (Schievano et al., 2008).

Biogas production is measured at intervals either qualitatively or quantitatively. Qualitative biogas assay is done by GC while the extrapressure gas is withdrawn by a syringe to quantitatively estimate biogas production (Schievano et al., 2008). GC is an optimal analytical tool for measuring components such as $\mathrm{CH}_{4}, \mathrm{CO}_{2}, \mathrm{H}_{2} \mathrm{~S}$, and siloxanes that constitute biogas (Zaman, 2010).

Equation 2 (Mayer et al., 2014) was used to calculate biomethane yield from ABP values of maize silages.

Biomethane yield $=\left(\% \mathrm{CH}_{4} \times \mathrm{ABP}\right) \times(\mathrm{VS} \times$ biomass yield $)$

(Eq. 2)

Where $\% \mathrm{CH}_{4}$ is the methane content in the biogas and VS is the volatile solids content of the biomass. 
Table 7.

Effects of some process parameters that influence the BMP test.

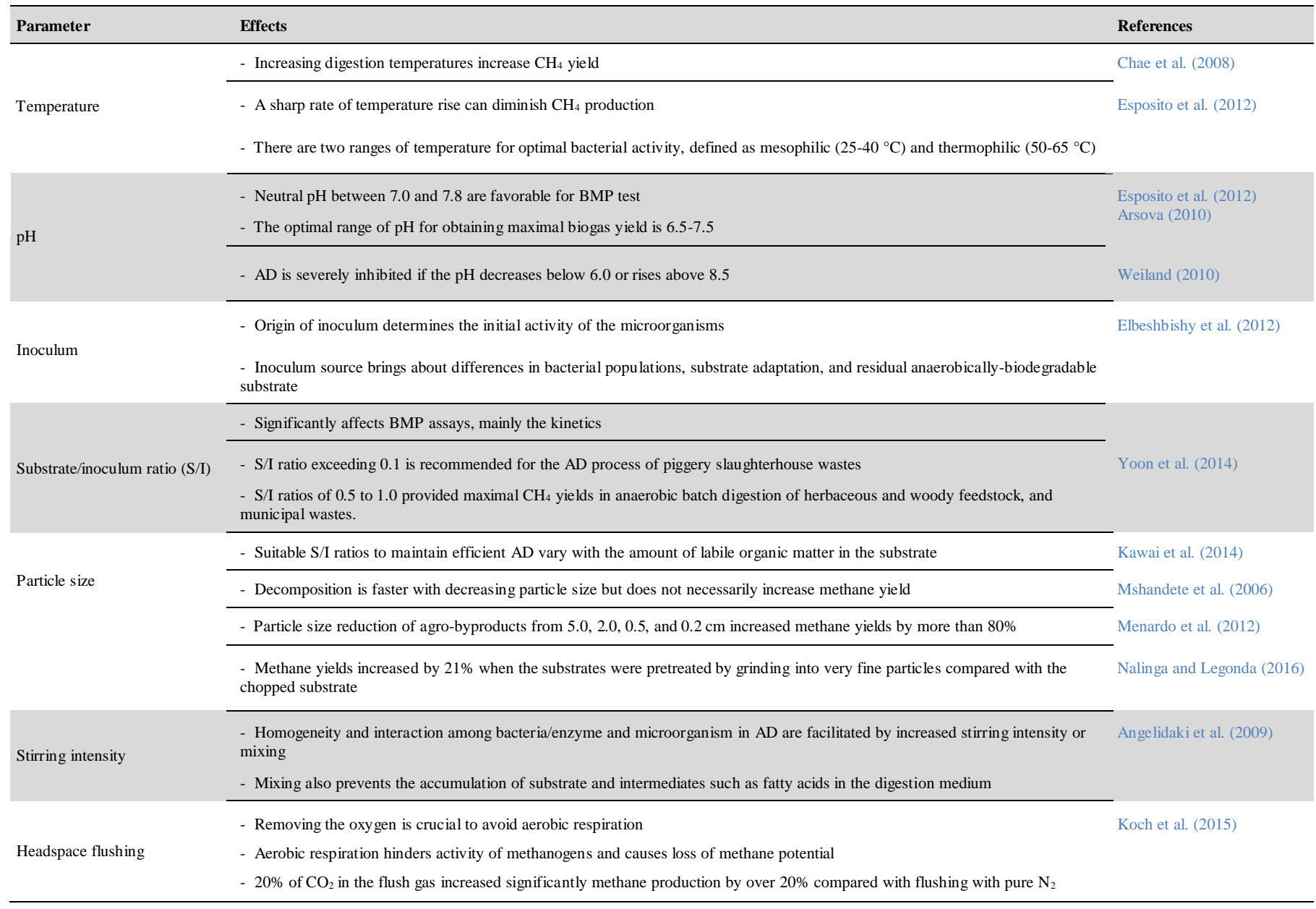

\subsubsection{A utomatic BMP test}

In order to reduce demerits of the conventional BMP test, new instruments have been designed to analyse the AD process as well as biogas yield and composition. One such instrument is the Automatic Methane Potential Test System (AMPTS) developed by the Bioprocess Control Sweden Company (Shi, 2012). Although the AMPTS removes $\mathrm{CO}_{2}$ and other acid gas in the biogas before estimating the $\mathrm{CH}_{4}$ yield, the instrument utilises the basic principle of the conventional BMP test. Methane production is directly measured on-line by means of liquid displacement and buoyancy method. The AMPTS provides high quality data with minimum labour requirements (Shi, 2012).

Angelidaki et al. (1998) developed a computerised automatic biogas activity monitoring (BAM) system for assessing the production of gas in closed vials. The system was applied to monitor the specific biogas activity of granular sludge from an upflow anaerobic sludge blanket reactor (Angelidaki et al., 1998). The BAM test consists of granular sludge seed mixed with sodium bicarbonate buffer in serum vessels sealed with butyl rubber corks. The reactors are incubated together with constant stirring.

The components of the system include a pressure transducer to assess the pressure accumulation by a motor driven multiport sampling port in a sequence of up to 16 test vessels. The multiport port is connected by means of an interface power circuit to a standard $\mathrm{PC}$ computer equipped with $\mathrm{I} / \mathrm{O}$ card to measure the amount of gas evolved (Zaman, 2010).

\subsubsection{Spectroscopy}

Spectroscopic techniques determine the absorbance, transmission, diffusion, or fluorescence of radiation in the ultraviolet (UV), visible (VIS), and infrared (IR) range (Spanjers and van Lier, 2006; Esteves et al., 2012). The basic components of spectroscopic instruments encompass a radiation source, a wavelength selector, sample cell, reagent dosing unit (for VIS spectrometry), detector, as well as data treatment and readout unit, and best suit automated in-line measurements (Spanjers and van Lier, 2006). Spectroscopic techniques include atomic spectroscopy which measures substances in gaseous phase after volatilisation and molecular spectroscopy which measures substances directly in liquids (Spanjers and van Lier, 2006).

IR spectroscopy methods rely on bond interactions. These methods contain information on the structure of dissolved compounds and identify components by comparison of a spectrum with reference spectra (Spanjers and van Lier, 2006). Common examples of IR spectroscopic instruments are near-infrared spectroscopy (NIR) and the Fourier transform midinfrared spectroscopy (FTIR). IR spectrum methods can monitor aromatic and aliphatic hydrocarbons, and chlorinated hydrocarbons (Spanjers and van Lier, 2006). The Envital ${ }^{\circledR}$ kit based on fluorescence redox indicator is a tool in its infant stages for determining BMP (Bellaton et al., 2016). 


\subsubsection{Near-infrared spectroscopy}

NIR is a useful tool for quantitative prediction of compounds in pharmaceutical, food, and agricultural industries (Ward, 2016). Recently, it has emerged as a simple and cheap alternative to several laboratory methods for the quantification of BMP (Ward, 2016). The method has been used in conjunction with sophisticated chemometrics to determine BMP (Bekiaris et al., 2015). NIR radiation varies from 12,821 and $3,959 \mathrm{~cm}^{-1}$. This is an ideal range for quantification of compounds as compared to mid-infrared spectroscopy (MIR) that has limitations due to interference with water. NIR spectroscopy method is sensitive to $\mathrm{C}-\mathrm{H}, \mathrm{N}-\mathrm{H}$, and $\mathrm{O}-\mathrm{H}$ bond interactions. Thus, compounds with these bonds are considered to be IR active, and can be measured directly (Ward, 2016). NIR spectrum can predict enzymaticallydigestible OM (eDOM) of organics with properly simulated models (Godin et al., 2015).

The prediction performances based on NIR spectrum are exceptionally good (Godin et al., 2015). The NIR-based prediction models provide an indirect fast, inexpensive, and simple way to predict the BMPs of various feedstocks (Godin et al., 2015). The method has been used for estimating the BMP of meadow grasses (Raju et al., 2011), fibrous plant biomasses (Triolo et al., 2014), numerous organic substrates (Lesteur et al., 2011; Doublet et al., 2013), and Miscanthus giganteus, switch grass, spelt straw, fibre sorghum, tall fescue, and fibre corn (Godin et al., 2015). However, before the NIR is operated, many barriers need to be overcome, especially with respect to uncertainty due to the poor standard error of laboratory of the reference method (Ward, 2016).

\subsubsection{Fourier transform mid-infrared spectroscopy}

The first efforts to measure BMP using FITR were performed by Bekiaris et al. (2015). The technology has been proven to be suitable for in-line determination of volatile fatty acids (VFA), alkalinity, COD, and TOC (Spanjers and van Lier, 2006). FITR utilises just a small amount of the sample determination, and requires the interpretation of the obtained spectra which is more difficult with NIR spectroscopy due to overlapping overtones and combination bands (Bekiaris et al., 2015).

The instrument is not new, but modifying with highly sensitive microphones have provided an advanced version of the FITR, and diversified its uses. The conventional FITR is merged with the photoacoustic detector to form the FTIR-photoacoustic spectroscopy (FTIR-PAS) (Bekiaris et al., 2015). The major drawback of reflectance or transmittance detection with conventional FTIR is that the measurement is influenced by the redistribution of light as a result of scattering effects and diffraction processes (Kizil and Irudayaraj, 2013).

The fundament of FTIR-PAS is to create a thermal wave from the vibration of molecules as a result of the infrared and the sample interface (Bekiaris et al., 2015). The thermal wave generates thermal expansion and pressure oscillation in the surrounding gas. This is detected as an acoustic signal by the microphone (Bekiaris et al., 2015). According to Kizil and Irudayaraj (2013), the acoustic signal is equivalent to the quantity of IR radiation in the sample. This permits the technology to be applicable on dark and opaque samples, and thus eliminates the scattering effects and diffraction processes of the traditional FITR (Kizil and Irudayaraj, 2013). To date, the FTIR-PAS has been applied by Bekiaris et al. (2015) to determine the BMP of various plant biomasses and the chemical components of plant materials that are associated with BMP.

\subsubsection{The Envital ${ }^{\circledR}$ kit}

Recently Bellaton et al. (2016) introduced a rapid assay based on fluorescence, the Envital ${ }^{\circledR}$ kit, to estimate anaerobic biodegradability of sewage sludge. This is a tool still in early stages of development. The assay produces results in $48 \mathrm{~h}$. It uses a fluorescent redox indicator.

Comparison of the results with AMPTS II confirmed the estimated values of BMP according to an uncertainty limit of $25 \%$ (Bellaton et al., 2016).

\subsection{Theoretical methods}

Regression models have also been used to estimate BMP (Triolo et al, 2011). These methods are fast. Theoretical studies are significant, especially in cases where access to laboratory facilities is limited (Thomsen et al., 2014).
Thorough data collection is required to obtain relevant data for determining potential regression models.

Several theoretical approaches are available to estimate BMP (Labatut et al., 2011). These assume that the substrate will be completely degraded and the use of the substrate by microorganisms as an energy source is insignificant (Forgacs, 2012). The main drawback associated with theoretical approaches is that the accuracy of each method mostly relies on the data of substrate composition and its biodegradable fraction, in particular (Labatut et al., 2011). In addition, the calculated BMP by theoretical methods cannot represent a realistic picture of BMP as it is often higher than the measured $\mathrm{CH}_{4}$ (Labatut et al., 2011). The potential degradation may be limited by biodegradability and ultimate production of inhibitors (Teghammar, 2013). Theoretical BMP can be estimated from elemental composition, chemical composition/component composition, and COD of a given biomass (Forgacs, 2012).

\subsubsection{Elemental composition}

The elemental composition (carbon $(\mathrm{C})$, hydrogen $(\mathrm{H})$, oxygen $(\mathrm{O})$, sulphur (S), and nitrogen $(\mathrm{N})$ ) of a substrate can be applied to calculate theoretical BMP. An example is the Buswell formula (Labatut et al., 2011; Thomsen et al., 2014). This stoichiometric formula was derived by Symons and Buswell (1933) from theoretical and laboratory studies of AD of carbohydrates (Thomsen et al., 2014). The Buswell equation is based on the assumption that $\mathrm{OM}$ (e.g., $\mathrm{C}_{\mathrm{n}} \mathrm{H}_{\mathrm{a}} \mathrm{O}_{\mathrm{b}}$ ) is completely degraded to $\mathrm{CH}_{4}$ and $\mathrm{CO}_{2}$ (Wang, 2016). The other product of $\mathrm{AD}$ is ammonia (Thomsen et al., 2014). The Buswell formula (Eq.3) is computed from the following chemical sum formula of the organic material:

$\mathrm{C}_{\mathrm{n}} \mathrm{H}_{\mathrm{a}} \mathrm{O}_{\mathrm{b}}+\left(\mathrm{n}-\frac{\mathrm{a}}{4}-\frac{\mathrm{b}}{2}\right) \cdot \mathrm{H}_{2} \mathrm{O} \longrightarrow\left(\frac{\mathrm{n}}{2}+\frac{\mathrm{a}}{8}-\frac{\mathrm{b}}{4}\right) \cdot \mathrm{CH}_{4}+\left(\frac{\mathrm{n}}{2}-\frac{\mathrm{a}}{8}+\frac{\mathrm{b}}{4}\right) \cdot \mathrm{CO}_{2}$

The Buswell formula can be applied to estimate BMP of cellulose, hemicellulose, protein, lipids, and so on of biomass, provided the proximate composition data are given, and the substrate is biodegradable. In this circumstance, exceptions are non-degradable biomass components such as ash and lignin (Thomsen et al., 2014). The Buswell equation has been used to predict the BMP of various substrates. For example, the BMP of lipid and cellulose were estimated at $1018 \mathrm{~L} \mathrm{~kg}^{-1}$ and $415 \mathrm{~L} \mathrm{~kg}^{-1}$, respectively (Triolo et al., 2011).

Feng et al. (2013) also estimated the BMP of vinegar residue based on the Buswell formula. Two reactions were applied as described by Sosnowski et al. (2003) (Eqs. 4 and 5). These are shown below of which Equation 4 is the Buswell formula:

$\mathrm{C}_{\mathrm{n}} \mathrm{H}_{\mathrm{a}} \mathrm{O}_{\mathrm{b}} \mathrm{N}_{\mathrm{c}}+\left(\mathrm{n}-\frac{\mathrm{a}}{4}-\frac{\mathrm{b}}{2}+\frac{3 \mathrm{c}}{4}\right) \cdot \mathrm{H}_{2} \mathrm{O} \longrightarrow\left(\frac{\mathrm{n}}{2}+\frac{\mathrm{a}}{8}-\frac{\mathrm{b}}{4}\right) \cdot \mathrm{CO}_{2}+\left(\frac{\mathrm{n}}{2}-\frac{\mathrm{a}}{8}+\frac{\mathrm{b}}{4}\right) \cdot \mathrm{CH}_{4}+\mathrm{cNH}_{3}$ (Eq. 4$)$

$\operatorname{TMBP}\left(\mathrm{mL} \mathrm{CH}_{4} \mathrm{~g} \mathrm{VS}^{-1}\right)=\frac{22.4 \times \frac{\mathrm{n}}{2}+\frac{\mathrm{a}}{8}-\frac{\mathrm{b}}{4}-\frac{3 \mathrm{z}}{8}}{12 \mathrm{n}+\mathrm{a}+16 \mathrm{~b}+14 \mathrm{c}}$

The theoretical BMP of vinegar residue was $473.34 \mathrm{~mL} \mathrm{CH}_{4} \mathrm{~g} \mathrm{VS}^{-1}$ using Equation 5 (Feng et al., 2013).

The modified Dulong formula can also be applied to estimate the theoretical maximum $\mathrm{CH}_{4}$ yields of all types of wastes (Browne and Murphy, 2013). This is based on energy value of the feedstock that is estimated from its elemental composition. For example, given the $\mathrm{CH}_{4}$ energy value of $37.78 \mathrm{MJm}^{-3}$, the theoretical maximum $\mathrm{CH}_{4}$ value was estimated at $560 \mathrm{~L} \mathrm{CH}_{4} \mathrm{~kg} \mathrm{VS}^{-1}$ added (Browne and Murphy, 2013). The modified Dulong formula (Eq. 6) is:

$\mathrm{E}^{\circ}=337 \mathrm{C}+1419(\mathrm{H}-1 / 8 \mathrm{O})+93 \mathrm{~S}+23.26 \mathrm{~N}$

Where, $\mathrm{E}^{\circ}$ represents the energy value of the substrate.

Bioenergetics and stoichiometry of biological reactions of McCathy (1972) cited by Labatut et al. (2011) is yet another theoretical method based on elemental composition analysis. This method makes use of the free energies of microbiologically-mediated balanced reactions to estimate cell yield and the overall stoichiometry related to growth and determine which fraction of a particular organic substrate (i.e., electron donor) is used for 
energy $\left(f_{e}\right)$ and which fraction is used for synthesis of cellular material $\left(f_{s}\right)$ (Labatut et al., 2011). Microbially-mediated reactions are redox reactions and involve the transfer of electrons (Zhou, 2010). Electron donors include carbonaceous compounds such as glucose, methanol, ethanol, acetate, aspartate, or formic acid as well as industrial wastes consisting of molasses, whey, distillery stillage, and sulphite waste liquor while nitrates or nitrites are electron acceptors (Zhou, 2010). Like the Buswell formula, this method does not consider biodegradability (Labatut et al., 2011).

\subsubsection{Chemical composition analyses}

The feedstock chemical characteristics such as the chemical composition (lignin, cellulose, hemicelluloses, starch, total soluble sugars, proteins, and lipids) can determine the gas generation by AD (Godin et al., 2015). The method is applicable in cases where elemental composition of the substrate is unknown. This can be done economically within a short period of time. The chemical composition analysis is a more rapid and cheaper method than the BMP test, provided appropriate models are developed and applied (Godin et al., 2015).
Rath et al. (2013) has provided empirical evidence to show that the chemical composition of corn (lignin, total soluble sugars, hemicelluloses, and lipids) gives a consistent model for estimation of BMP. At least two variables are required to build a reliable model (Godin et al., 2015). The chemical composition of fruit and vegetable wastes, sorghum and napier grass (carbohydrate, protein, acid detergent fibre, lignin and cellulose contents of substrate) were used to predict the ultimate methane yield (Gunaseelan, 2007).

\subsubsection{Chemical oxygen demand}

COD indirectly measures the amount of organic matter, and for that reason, it can be applied to estimate the $\mathrm{CH}_{4}$ yield of biomass substrate (Forgacs, 2012). This method is based on the assumption that 1 mole of methanerequires 2 moles of oxygen to oxidise carbon to carbon-dioxide and water (Eq. 7). Every g of methane is thus equivalent to $4 \mathrm{~g}$ of COD (Forgacs, 2012).

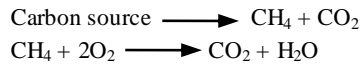

Table 8 .

Advantages and disadvantages of various methods used to determine BMP.

\begin{tabular}{|c|c|c|c|}
\hline Method & Advantages & Disadvantages & References \\
\hline \multicolumn{4}{|l|}{ BMP test } \\
\hline Conventional & $\begin{array}{ll}- & \text { Easy to use } \\
- & \text { Inexpensive } \\
- & \text { Repeatable }\end{array}$ & $\begin{array}{ll}\text { - } & \text { Time wasting } \\
\text { - } & \text { Resource consuming }\end{array}$ & Rodriguez (2011); Esposito et al. (2012) \\
\hline Automatic & $\begin{array}{l}\text { - Uses less labour } \\
\text { The equipment is inexpensive } \\
\text { Provides high quality and adequate quantity of } \\
\text { data }\end{array}$ & - $\quad$ Require sound systems & Shi (2012) \\
\hline \multicolumn{4}{|l|}{ Spectroscopy } \\
\hline Near-infrared spectroscopy & $\begin{array}{ll}\text { - } & \text { Rapid } \\
\text { - } & \text { Chemical-free } \\
\text { Easy to use (once calibrations have been } \\
\text { developed) }\end{array}$ & $\begin{array}{l}\text { - } \quad \text { Machines are too expensive } \\
\text { - } \quad \text { Salibration is less accurate than wet chemistry } \\
\text { overconfidence } \\
\text { Measurement outside of range of calibration } \\
\text { samples is invalid }\end{array}$ & Manley (2014) \\
\hline $\begin{array}{l}\text { Fourier transform mid- } \\
\text { infrared spectroscopy }\end{array}$ & $\begin{array}{l}\text { - } \quad \text { Relatively fast and simple to use } \\
\text { - } \\
\text { Nensitive and requires small amount of sample } \\
\text { Universal method: the instrument and software } \\
\text { readily available and can be utilised for routine } \\
\text { analysis } \\
\text { Multiple sample analysis: can test samples in the } \\
\text { form of liquid, gas, powder, solid or film } \\
\text { Relatively cheap as compared to many other } \\
\text { methods } \\
\text { Provides qualitative as well as quantitative data }\end{array}$ & $\begin{array}{l}\text { A single sample requires background scans and } \\
\text { many scans due to variations in the spectra } \\
\text { caused by environmental factors surrounding } \\
\text { the FT-IR spectrophotometer } \\
\text { May require standardisation, extensive data } \\
\text { collection and skills in chemometric analysis } \\
\text { of spectra }\end{array}$ & Davis and Mauer (2010) \\
\hline The Envital ${ }^{\circledR}$ kit & $\begin{array}{l}\text { - } \quad \text { Rapid } \\
\text { High-through put characterisation of more than } \\
32 \text { samples simultaneously in } 48 \text { hours } \\
\text { - } \quad \text { Quickly answers operational requests }\end{array}$ & $\begin{array}{l}\text { - } \quad \text { Still in early stages of development } \\
\text { - }\end{array}$ & Bellaton et al. (2016) \\
\hline Theoretical methods & $\begin{array}{l}\text { - } \quad \text { Rapid } \\
\text { - } \quad \text { Useap } \\
\text { facilities is restricted }\end{array}$ & $\begin{array}{l}\text { The accuracy of each method presumes } \\
\text { complete degradation of organic matter, yet the } \\
\text { actual digestibility is usually } 27-76 \% \text {. } \\
\text { - The BMP is over-estimated. } \\
\text { - Several inhibitions may occur during the } \\
\text { digestion process, and are not considered in } \\
\text { these methods } \\
\text { Requires a lot of measurements which time } \\
\text { consuming and costly }\end{array}$ & $\begin{array}{l}\text { Labatut et al. (2011); Teghammar (2013); } \\
\text { Fogacs (2012) }\end{array}$ \\
\hline
\end{tabular}


From Equation 7 above, each $\mathrm{kg}$ of COD corresponds to $0.35 \mathrm{~m}^{3}$ of methane gas at standard temperature and pressure (Forgacs, 2012)

\subsection{Summary of advantages and disadvantages of various methods}

Some advantages and disadvantages of the various methods of BMP determination have been given in the preceding sections. Table 8 provides a summary of the advantages and disadvantages of various methods.

It is clear in Table 3 that the BMP test scores high on validity and reliability of its results. This is mainly because it uses feedstocks in experimental conditions that mimic $\mathrm{AD}$ conditions in real practice. However, its main disadvantage is the time needed to obtain results, in comparison with other methods.

It should be pointed out that spectroscopy and theoretical methods have application in certain circumstances. Both are widely used and have produced reliable results. Their main disadvantage is that they are not based on in situ test parameters. What is worth noting is the continued work to improve the reliability and validity of these methods.

\section{Conclusions}

Several tools exist to determine the BMP of feedstocks. These range from theoretical to experimental tools. The BMP assay is a good toolkit to use for the determination of BMP. It has high reliability and validity as it is based on conditions that approximate practical AD processes. This paper has presented the advantages of the BMP test when compared with other methods. The issue of time consuming is debatable and can be easily counteracted by the quality of the results.

The paper has also shown the utility of spectroscopy and theoretical methods in determination of BMP. More interestingly, this is juxtaposed with the BMP test. Thus, the paper provides data on technical aspects of the methods, their advantages and disadvantages in a synchronous manner. This facilitates easy comparative analysis and shows the trend towards improvement of the methods.

\section{References}

[1] Abbassi-Guendouz, A., Brockmann, D., Trably, E., Dumas, C., Delgene`s, J.P., Steyer, J.P., Escudie, R., 2012. Total solids content drives high solid anaerobic digestion via mass transfer limitation. Bioresour. Technol. 111, 55-61.

[2] Adhikari, R., 2006. Sequential batch and continuous anaerobic digestion of municipal solid waste in pilot scale digesters. MSc Thesis, Asian Institute of Technology, Thailand.

[3] Al Seadi, T., Ruiz, D., Prassl, H., Kottner, M., Finsterwaldes, T., Volke, S., Janssers, R., 2008. Handbook of Biogas, University of Southern Denmark, Esbjerg.

[4] Allen, E., Browne, J.D., Murphy, J.D., 2013. Evaluation of the biomethane yield from anaerobic co-digestion of nitrogenous substrates. Environ. Technol. 34(13-14), 2059-2068.

[5] Amon, T., Amon, B., Kryvoruchlo, V., Machmuller, A., Hopfner-Sixt, K., Bodiroza, V., Hrbek, R., Friedel, J., Potsch, E., Wagentristl, H., Schreiner, M., 2007. Methane production through anaerobic digestion of various energy crops grown in sustainable crop rotations. Bioresour. Technol. 98(17), 3204-3212

[6] Angelidaki, I., Alves, M., Bolzonella, D., Borzaconni, L., Campos, J.L., Guwy, A.J., Kalyuzhnyi, S., Jenicek, P., van Lier, J.B., 2009. Defining the biomethane potential (BMP) of solid organic wastes and energy crops: a proposed protocol for batch assays. Water Sci. Technol. 59(5), 927-934.

[7] Angelidaki, I., Sanders, W., 2004. Assessment of the anaerobic biodegradability of macropollutants. Rev. Environ. Sci. Biotechnol. 3(2), 117-129.

[8] Angelidaki, I., Schmidt, J.E., Ellegaard, L., Ahring, B.K., 1998. An automatic system for simultaneous monitoring of gas evolution in multiple closed vessels. J. Microbiol. Methods. 33(1), 93-100.

[9] Arsova, L., 2010. Anaerobic digestion of food waste: current status, problems and an alternative product. MSc Thesis, Columbia University, New York, USA.
[10] Babaee, A., Shayegan, J., 2011. Effect of organic loading rates (OLR) on production of methane from anaerobic digestion of vegetables waste. World Renewable Energy Congr. (WREC). 8-13. Linköping.

[11] Badshah, M., Lam, D.M., Liu, J., Mattiasson, B., 2012. Use of an automatic methane potential test system for evaluating the biomethane potential of sugarcane bagasse after different treatments. Bioresour. Technol. 114, 262-269.

[12] Bekiaris, G., Triolo, J.M., Peltre, C., Pedersen, L., Jensen, L.S., Bruun, S., 2015. Rapid estimation of the biochemical methane potential of plant biomasses using fourier transform mid-infrared spectroscopy photoacoustic spectroscopy. Bioresour. Technol. 197, 475-481.

[13] Bellaton, S., Guérin, S., Pautremat, N., Bernier, J., Muller, M. Motellet, S., Azimi, S., Pauss, A., Rocher, V., 2016. Early assessment of a rapid alternative method for the estimation of the biomethane potential of sewage sludge. Bioresour. Technol. 206, 279-284.

[14] Braun, R., Weiland, P., Wellinger, A., 2009. Biogas from energy crop digestion. IEA Task 37 Brochure, International Energy Agency, Paris

[15] Browne, J.D., Murphy, J.D., 2013. Assessment of the resource associated with biomethane from food waste. Appl. Energy. 104, 170177.

[16] California Integrated Waste Management Board (CIWMB), 2008. Current anaerobic digestion technologies used for treatment of municipal of organic waste.

[17] Chae, K.J., Jang, A.M., Yim, S.K., Kim, I.S., 2008. The effects of digestion temperature and temperature shock on the biogas yields from the mesophilic anaerobic digestion of swine manure. Bioresour. Technol. 99(1), 1-6.

[18] Chandra, R., Takeuchi, H., Hasegawa, T., 2012. Methane production from lignocellulosic agricultural crop wastes: a review in context to second generation of biofuel production. Renew. Sust. Energy Rev. 16(3), 1462-1476

[19] Chen, Y., Cheng, J.J., Creame, K.S., 2008. Inhibition of anaerobic digestion process: a review. Bioresour. Technol. 99(10), 4044-4064.

[20] Corno, L., Pilu, R., Adani, F., 2014. Arundo donax L.: a non-food crop for bioenergy and bio-compound production. Biotechnol. Adv. 32(8), 1535-1549.

[21] Davis, R., Mauer, L.J., 2010. Fourier tansform infrared (FT-IR) spectroscopy: a rapid tool for detection and analysis of foodborne pathogenic bacteria, in: Mendez-Vilas, A. (Ed.), Current research, technology and education topics in applied microbiology and microbial biotechnology. Formatex Research Center, Indiana, pp. 2, $1582-1594$

[22] De Baere, L.A., Devocht, M., Van Assche, P., Verstraete, W., 1984. Influence of high $\mathrm{NaCl}$ and $\mathrm{NH}_{4} \mathrm{Cl}$ salt levels on methanogenic associations. Water Res. 18(5), 543-548.

[23] De Clercq, D., Wen, Z., Fan, F., Caicedo, L., 2016. Biomethane production potential from restaurant food waste in megacities and project level-bottlenecks: a case study in Beijing. Renew. Sust. Energy Rev. 59, 1676-1685.

[24] De Mes, T.Z.D., Stams, A.J.M., Reith, J.H., Zeeman, G., 2003. Methane production by anaerobic digestion of wastewater and solid wastes, in: Reith, J.H., Wijffels, R.H., Barten, H. (Eds.), Bio-methane and Biohydrogen: status and perspectives of biological methane and hydrogen production. Dutch Biological Hydrogen Foundation, Petten, pp. 58-102

[25] Deublein, D., Steinhauser, A., 2010. Biogas from waste and renewable sources: an introduction. John Wiley \& Sons.

[26] Dioha, I.J., Ikeme, C.H., Nafi'u, T., Soba, N.I., Yusuf, M.B.S., 2013. Effect of carbon to nitrogen ratio on biogas production. Int. Res. J. Nat. Sci. 1(3), 1-10

[27] Doublet, J., Boulanger, A., Ponthieux, A., Laroche, C., Poitrenaud, M., Cacho Rivero, J.C., 2013. Predicting the biochemical methane potential of wide range of organic substrates by near infrared spectroscopy. Bioresour. Technol. 128, 252-258.

[28] Elbeshbishy, E., Nakhla, G., Hafez, H., 2012. Biochemical methane potential (BMP) of food waste and primary sludge: influence of inoculum pre-incubation and inoculum source. Bioresour. Technol. $110,18-25$ 
[29] Ertem, F.C., 2011. Improving biogas production by anaerobic digestion of different substrates: calculation of potential energy outcomes. MSc Thesis, Halmstad University, Halmstad.

[30] Esposito, G., Frunzo, L., Liotta, F., Panico, A., Pirozzi, F., 2012. Biomethane potential tests to measure the biogas production from the digestion and co-digestion of complex organic substrates. Open Environ. Eng. J. 5, 1-8.

[31] Esteves, S., Miltner, M., Fletch, S., 2012. Monitoring review and guide for the optimisation of anaerobic digestion and biomethane plants. Full Report.

[32] European Communities (EC), 2002. Proceedings of the workshop on hamornisation anaerobic biodegradation, Activity and Inhibition Assays, Lago d'Orta, Italy.

[33] Feng, L., Li, Y., Chen, C., Liu, X., Xiao, X., Ma, X., Zhang, R., He, Y., Liu, G., 2013. Biochemical methane potential (BMP) of vinegar residue and the influence of feed to inoculums ratios on biogas production. Bioresources. 8(2), 2487-2498.

[34] Fogacs, G., 2012. Biogas production from citrus wastes and chicken feather: pretreatment and co-digestion. PhD Thesis, Chalmers University of Technology, Göteborg.

[35] Forster-Carneiro, T., Pe'rez, M., Romero, L.I., 2008. Influence of total solid and inoculum contents on performance of anaerobic reactors treating food waste. Bioresour. Technol. 99(15), 6994-7002.

[36] Gao, R., Yuan, X., Zhu, W., Wang, X., Chen, S., Cheng, X., Cui, Z., 2012. Methane yield through anaerobic digestion for various maize varieties in China. Bioresour. Technol. 118, 611-614.

[37] Gerardi, M.H., 2003. The microbiology of anaerobic digesters, John Wiley \& Sons.

[38] Godin, B., Mayer, F., Agneessens, R., Gerin, P., Dardenne, P., Delfosse, P., Delcarte, J., 2015. Biochemical methane potential prediction of plant biomasses: comparing chemical composition versus near infrared methods and linear versus non-linear models. Bioresour. Technol. 175, 382-390.

[39] Gunaseelan, V.N., 2004. Biochemical methane potential of fruits and vegetable solid waste feedstocks. Biomass Bioenergy. 26(4), 389-399.

[40] Gunaseelan, V.N., 2007. Regression models of ultimate methane yields of fruits and vegetable solid wastes, sorghum and napiergrass on chemical composition. Bioresour. Technol. 98(6), 1270-1277.

[41] Hamilton, D.W., 2012. Organic matter content of wastewater and manure. BAE 1760, Oklahoma Cooperative Extension Service, Stillwater, Oklahoma.

[42] Hansen, T.L., Schmidt, J.E., Angelidaki, I., Marca, E., la Cour Jansen, J., Mosbaek, H., Christensen, T.H., 2004. Method for determination of methane potentials of solid organic waste. Waste Manage. 24(4), 393400

[43] Hobbs, P., Ward, A., Pardo, G., 2007. Biogas for agriculture, Iger Innovations.

[44] Horváth, I.S., Tabatabaei, M., Karimi, K., Kumar, R., 2016. Recent updates on biogas production-a review. Biofuel Res. J. 3(2), 394-402.

[45] Hussain, A., Dubey, S.K., 2017. Specific methanogenic activity test for anaerobic degradation of influents. Appl. Water Sci. 7(2), 535-542.

[46] International Energy Agency, 2009. Biogas production and utilization, IEA Task 37 Brochure. International Energy Agency, Paris.

[47] International Energy Agency, 2013. Biogas production and utilization.

[48] Isci, A., Demir, G.N., 2007. Biogas production potential from cotton wastes. Renewable Energy. 32(5), 750-757.

[49] ISO 11734, 1995. Water quality-evaluation of the "ultimate" anaerobic biodegradability of organic compounds in digested sludge-method by measurement of the biogas production. ISO Guideline 11734, European Committee for Standardization, Brussels.

[50] Ivo Achu, N., 2012. Anaerobic digestion of crop and waste biomass: impact of feedstock characteristics on process performance. $\mathrm{PhD}$ Thesis, Lund University (Media-Tryck), Sweden.

[51] Jijai, S., Srisuwan, G., O-thong, S., Ismail, N., Siripatana, C., 2014. Specific methanogenic activities (SMA) and biogas production of different granules size and substrates. The $1^{\text {st }}$ Environment and Natural Resources International Conference, The Sukosol hotel, Bangkok, Thailand, pp. 1-4.
[52] Jingura, R.M., Musademba, D., Matengaifa, R., 2010. An evaluation of utility of Jatropha curcas L. as a source of multiple energy carriers. Int. J. Eng. Sci. Technol. 2(7), 115-122.

[53] Kawai, M., Nagao, N., Tajima, N., Niwa, C., Matsuyama, T., Toda, T., 2014. The effect of the labile organic fraction in food waste and the substrate/inoculum ratio on anaerobic digestion for a reliable methane yield. Bioresour. Technol. 157, 174-180.

[54] Khalid, A., Arshad, M., Anjum, M., Mahmood, T., Dawson, L., 2011. Review-the anaerobic digestion of solid organic waste. Waste Manage. 31(8), 1737-1744.

[55] Kizil, R., Irudayaraj, J., 2013. Fourier transform infrared photoacoustic spectroscopy (FTIR-PAS), in: Roberts, G. (Ed.), Encyclopaedia of Biophysics: Springer Reference. Springer-Verlag, Berlin, Heidelberg, pp. 880-844.

[56] Koch, K., Fernández, Y.B., Drewes, J.E., 2015. Influence of headspace flushing on methane production in biochemical methane potential (BMP) tests. Bioresour. Technol. 186, 173-178.

[57] Korres, N., O'Kiely, P., Benzie, J.A., West, J.S., 2013. Bioenergy production by anaerobic digestion: using agricultural biomass and organic wastes. Routledge, Taylor \& Francis Publishing Group, London, pp. 442

[58] Kuusik, A.R.G.O., Kuusik, A.A.R.E., Loigu, E., Sokk, O.L.E.V., 2013. Predicting preferable substrate blends for the production of biogas. Proceedings of the $9^{\text {th }}$ International Conference on Energy, Environment, Ecosystems and Sustainable Development (EEESD '13), Lemesos, Cyprus, pp. 192-197.

[59] Kwietniewska, E., Tys, J., 2014. Process characteristics, inhibition factors and methane yields of anaerobic digestion process, with particular focus on microalgal biomass fermentation. Renew. Sust. Energy Rev. 34, 491-500.

[60] Labatut, R.A., Angenent, L.T., Scott, N.R., 2011. Biochemical methane potential and biodegradability of complex organic substrates. Bioresour. Technol. 102(3), 2255-2264.

[61] Lebersorger, S., Schneider, F., 2011. Discussion on the methodology for determining food waste in household waste composition studies. Waste Manage. 31(9-10), 1924-1933.

[62] Lesteur, M., Latrille, E., Bellon-Maurel, V.B., Roger, J.M., Gonzalez, C., Junqua, G., Steyer, J.P., 2011. First step towards a fast analytical method for the determination of biochemical methane potential of solid waste by near infrared spectroscopy. Bioresour. Technol. 102(3), 2280-2288.

[63] Mahmood, A., Ullah, H., Ijaz, M., Javaid, M.M., Shahzad, A.N., Honermeier, B., 2013. Evaluation of sorghum hybrids for biomass and biogas production. Aust. J. Crop Sci. 7(10), 1456-1462.

[64] Manley, M., 2014. Near-infrared spectroscopy and hyperspectral imaging: non-destructive analysis of biological materials. Chem. Soc. Rev. 43, 8200-8214.

[65] Mayer, F., Gerin, P.A., Noo, A., Foucart, G., Flammang, J., Lemaigre, S., Sinnaeve, G., Dardenne, P., Delfosse, P., 2014. Assessment of factors influencing the biomethane yield of maize silages. Bioresour. Technol. 153, 260-268.

[66] McCarty, P.L., 1972. Energetics of organic matter degradation, in: Mitchell, R. (Ed.), Water Pollution Microbiology. John Wiley \& Sons, Inc., New Jersey, pp. 91-118.

[67] Menardo, S., Airoldi, G., Balsari, P., 2012. The effect of particle size and thermal pre-treatment on the methane yield of four agricultural by-products. Bioresour. Technol. 104, 708-714.

[68] Meng, Y., Li, S., Yuan, H., Zou, D., Liu, Y., Zhu, B., Chufo, A., Jaffer, M., Li, X., 2015. Evaluating biomethane production from anaerobic mono-and co-digestion of food waste and floatable oil (FO) skimmed from food waste. Bioresour. Technol. 185, 7-13.

[69] Monnet, F., 2003. An introduction to the anaerobic digestion of organic waste. Remade Scotland. 1-48.

[70] Moody, L.R., Burns, R., Wu-Haan, W., Spajić, R., 2009. Use of biochemical methane potential (BMP) assays for predicting and enhancing anaerobic digester performance. Proceedings of the 4th International and 44th Croatian Symposium of Agriculture, Optija. 
[71] Mshandete, A., Bjornsson, L., Kivaisi, A.K., Rubindamayugi, M.S., Matthiasson, B., 2006. Effect of particle size on biogas yield from sisal fibre waste. Renewable Energy. 31(14), 2385-2392.

[72] Nalinga, Y., Legonda, I., 2016. The effect of particles size on biogas production. Int. J. Innovative Res. Technol. Sci. 4(2), 9-13.

[73] Navarro-Pineda, F.S., Baz-Rodriguez, S.A., Handler, R., SacramentoRivero, J.C., 2016. Advances on the processing of Jatropha curcas towards a whole-crop biorefinery. Renew. Sust. Energy Rev. 54, 247-269.

[74] Nielfa, A., Cano, R., Fdz-Polanco, M., 2015. Theoretical methane production generated by the co-digestion of organic fraction municipal solid waste and biological sludge. Biotechnol. Rep. 5, 14-21.

[75] Noyola, A., Morgan-Sagastume, J.M., López-Hernández, J.E., 2006. Treatment of biogas produced in anaerobic reactors for domestic wastewater: odor control and energy/resource recovery. Rev. Environ. Science. Bio. 5(1), 93-114.

[76] Oslaj, M., Mursec, B., Vindis, P., 2010. Biogas production from maize hybrids. Biomass Bioenergy. 34(11), 1538-1545.

[77] Pavan, P., Battistoni, P., Mata-Alvarez, J., 2000. Performance of thermophilic semi-dry anaerobic digestion process changing the feed biodegradability. Water Sci. Technol. 41(3), 75-81.

[78] Pham, C.H., Triolo1, J.M., Cu, T.T.T., Pedersen, L., Sommer, S.G., 2013. Validation and recommendation of methods to measure biogas production potential of animal manure. Asian Australas. J. Anim. Sci. (AJAS). 26(6), 864-873.

[79] Raju, C.S., Ward, A.J., Nielsen, L., Moller, H.B., 2011. Comparison of near infra-red spectroscopy, neutral detergent fibre assay and in-vitro organic matter digestibility assay for rapid determination of the biochemical methane potential of meadow grasses. Bioresour. Technol. 102(17), 7835-7839.

[80] Raju, C.S., 2015. Optimization of the anaerobic digestion process by substrate pre-treatment and the application of NIRS. Technical report BCE-TR-1. Department of Engineering, Aarhus University., Denmark, pp. 96.

[81] Rath, J., Heuwinkel, H., Herrmann, A., 2013. Specific biogas yield of maize can be predicted by the interaction of four biochemical constituents. Bioenergy Res. 6(3), 939-952.

[82] Rodriguez Chiang, L.M., 2011. Methane potential of sewage sludge to increase biogas production. TRITA LWR Degree Project 11-22, Royal Institute of Technology, Stockholm.

[83] Scaglia, B., D’Imporzano, G., Garuti, G., Negri, M., Adani, F., 2014. Sanitation ability of anaerobic digestion performed at different temperature on sewage sludge. Sci. Total Environ. 466-467, 888-897.

[84] Schievano, A., Pognani, M., D’Imporzano, G., Adani, F., 2008. Predicting anaerobic biogasification potential of ingestates and digestates of full-scale biogas plant using chemical and biological parameters. Bioresour. Technol. 99(17), 8112-8117.

[85] Schievano, A., Scaglia, B., D’Imporzano, G., Malagutti, L., Gozzi, A., Adani, F., 2009. Prediction of biogas potentials using quick laboratory analyses: upgrading previous models for application to heterogeneous organic matrices. Bioresour. Technol. 100(23), 5777-5782.

[86] Schittenhelm, S., 2008. Chemical composition and methane yield of maize hybrids with contrasting maturity. Eur. J. Agron. 29(2-3), 72-79.

[87] Sell, S.T., Burns, R.T., Raman, D.R., Moody, L. B., 2010. Approaches for selecting anaerobic digestion co-substrates for a full-scale beef manure digester using biochemical methane potentials and anaerobic toxicity assays. Proceedings of the International Symposium on Air Quality and Manure Management for Agriculture, Agricultural and Biosystems Engineering Conference, Dallas Texas.

[88] Sepalla, M., 2013. Biogas production from high-yielding energy crops in boreal conditions. Academic Thesis, University of Jyväskylä, Jyväskylä, Finland.

[89] Shi, C., 2012. Potential biogas production from fish waste and sludge. MSc Thesis, Royal Institute of Technology (KTH), Stockholm.

[90] Singh, R.N., Vyas, D.K., Srivastava, N.S.L., Narra, M., 2008. SPERI experience on holistic approach to utilize all parts of Jatropha curcas fruit for energy. Renewable Energy. 33(8), 1868-1873.

[91] Sosnowski, P., Wieczorek, A., Ledakowicz, S., 2003. Anaerobic codigestion of sewage sludge and organic fraction of municipal solid wastes. Adv. Environ. Res. 7(3), 609-616.
[92] Spanjers, H., van Lier, J.B., 2006. Instrumentation in anaerobic treatment-research and practice. Water Sci. Technol. 53(4-5), 63-76.

[93] Speece, R.E., 1996. Anaerobic biotechnology for industrial wastewaters. Archae Press, Nashville, Tennessee.

[94] Strong, P.J., Kalyuzhnaya, M., Silverman, J., Clarke, W.P., 20 16. A methanotroph-based biorefinery: potential scenarios for generating multiple products from a single fermentation. Bioresour. Technol. 215, 314-323.

[95] Switzenbaum, M.S., 1995. Obstacles in the implementation of anaerobic treatment technology. Bioresour. Technol. 533(3), 255 262.

[96] Symons, G.E., Buswell, A.M., 1933. The methane fermentation of carbohydrates 1, 2. J. Am. Chem. Soc. 55(5), 2028-2036.

[97] Teghammar, A., 2013. Biogas production from lignocelluloses: pretreatment, substrate characterisation, co-digestion and economic evaluation. PhD Thesis, Chalmers University of Technology, Sweden.

[98] Thomsen, S.T., Spliid, H., Østergård, H., 2014. Statistical prediction of biomethane potentials based on the composition of lignocellulosic biomass. Bioresour. Technol. 154, 80-86.

[99] Triolo, J.M., Ward, A.J., Pedersen, L., Lokke, M.M., Qu, H., Sommer S.G., 2014. Near infrared reflectance spectroscopy (NIRS) for rapid determination of biochemical methane potential of plant biomass. Appl. Energy. 116, 52-57.

[100]Triolo, J.M., Sommer, S.G., Møller, H.B., Weisbjerg, M.R., Jiang, X.Y., 2011. A new algorithm to characterise biodegradability of biomass during anaerobic digestion: influence of lignin concentration on methane production potential. Bioresour. Technol. 102(20), 93959402.

[101]VDI 4630, 2006. Fermentation of organic materials-characterisation of the substrate, sampling, collection of material data, fermentation tests, VDI Guideline 4630. Verein Deutscher Ingenieure, Düsseldorf.

[102]Wall, D.M., O'Kiely, P., Murphy, J.D., 2013. The potential for biomethane from grass and slurry to satisfy renewable energy targets. Bioresour. Technol. 149, 425-431

[103]Wang, B., 2016. Factors that influence the biochemical methane potential (BMP) test. PhD Thesis, Lund University, Switzerland.

[104]Wang, X., Lu, X., Li, F., Yang, G., 2014. Effects of temperature and carbon-nitrogen $(\mathrm{C} / \mathrm{N})$ ratio on the performance of anaerobic codigestion of dairy manure, chicken manure and rice straw: focusing on ammonia inhibition. PLoS ONE. 9(5), e97265.

[105]Wang, B., Nges, I.A., Nistor, M., Liu, J., 2014. Determination of methane yield of cellulose using different experimental setups. Water Sci. Technol. 70(4), 599-604.

[106] Ward, A.J., 2016. Near-Infrared spectroscopy for determination of the biochemical methane potential: state of the art. Chem. Eng. Technol. 39(4), 611-619.

[107]Ward, A.J., Hobbs, P.J., Holliman, P.J., Jones, D.L., 2008. Optimisation of the anaerobic digestion of agricultural resources. Bioresour. Technol. 99(17), 7928-7940.

[108] Weiland, P., 2010. Biogas production: current state and perspectives. Appl. Microbiol. Biotechnol. 85(4), 849-860.

[109]Ye, Y., Zamalloa, C., Lin, H., Yan, M., Schmidt, D., Hu, B., 2015. Evaluation of anaerobic co-digestion of dairy manure with food wastes via bio-methane potential assay and CSTR reactor. J. Environ. Sci. Health, Part B. 50(3), 217-227.

[110]Yi, J., Dong, B., Jin, J., Dai, X., 2014. Effect of increasing total solids contents on anaerobic digestion of food waste under mesophilic conditions: performance and microbial characteristics analysis. PLoS ONE. 9(7), e102548.

[111]Yoon, Y.M., Kim, S.H., Shin, K.S., Kim, C.H., 2014. Effects of substrate to inoculum ratio on the biochemical methane potential of piggery slaughterhouse wastes. Asian Australas. J. Anim. Sci. 27(4), 600-607. 
[112]Qamaruz Zaman, N., 2010. The applicability of batch tests to assess biomethanation potential of organic waste and assess scale up to continuous reactor systems. $\mathrm{PhD}$ Thesis, University of Canterbury, Christchurch.

[113]Zhang, R., El-Mashad, H.M., Hartman, K., Wang, F., Liu, G., Choate, C., Gamble, P., 2007. Characterization of food waste as feedstock for anaerobic digestion. Bioresour. Technol. 98, 929-935.

[114]Zhou, H., Meng, A., Long, Y., Li, Q., Zhang, Y., 2014. Classification and comparison of municipal solid waste based on thermochemical characteristics. J. Air Waste Manage. Assoc. 64(5), 597-616.

[115]Zhou, S.Q., 2010. Theoretical stoichiometry of biological denitrifications. Environ. Technol. 22(8), 869-880. 